\title{
Constraints to Accessing Micro-Credit and Loan Scheme of Bank of Agriculture among Farmers in Enugu State, Nigeria: Implications for Extension Service Delivery
}

\author{
Mbah, E.N.*, Jiriko, R. \& Agada, M.O. \\ Department of Agricultural Extension and Communication, University of Agriculture Makurdi, Nigeria
}

\section{ABSTRACT}

The study examined constraints to accessing microcredit/loan scheme of Bank of Agriculture (BOA) among farmers in Enugu State, Nigeria: Implications for extension service delivery. Purposive and simple random sampling techniques were used in selecting one hundred (100) respondents for the study. Data were collected using structured interview schedule/questionnaire and analyzed using frequency, percentage, mean scores and standard deviation. The study revealed that micro-credit/ loan scheme $(88.6 \%)$ were the most patronized among the rural farmers. Others such as ECOWAS, IFAD project and ATHP programme were not patronized at all, probably because the type of projects sponsored by these credit/loan scheme are not important to the respondents. The respondents (farmers) were highly constrained by late release of funds $(M=1.27)$, grace period too short $(M=1$. 17), excessive bureaucracy $(M=1.14)$, too short payback period $(M=1.13)$, services not regular $(M=1.13)$, among others. The Bank of Agriculture staff also noted that they were constrained by late release of approved funds by head quarters of the Bank of Agriculture $(\mathrm{M}=1.43)$, loan diversion $(\mathrm{M}=1.27)$, poor funding of field officers $(\mathrm{M}=$ 1.20), lack of awareness by borrowers $(\mathrm{M}=1.10)$ and insufficient staff $(M=0.93)$. The study recommends that adequate awareness campaign on the availability of microcredit/loan scheme by Bank of Agriculture should be created in order for the beneficiaries to be knowledgeable about it. It highlights the need for approval of more funds under the scheme and timely release of funds when needed especially during planting season in order to enable the farmers to make judicious use of it for optimum productivity.

Key words: Bank of Agriculture, micro-credit, loan, farmers, programme, Nigeria

\section{Introduction}

Agriculture has been and is still the bedrock on which every successful and stable economy the world over is built. In Nigeria today, agriculture accounts for one third of the Gross Domestic Product (GDP) and employs about two third of the labour force (Oyeyinka, 2002).

Small-scale farmers in Nigeria are greatly involved in agriculture sector and produce the bulk of food and fiber used in the country (Ekong, 2003). Additionally, critical factors that affect productivity at the farm level include factors of production such as land, capital, agricultural research, technology, infrastructure and access to support service such as extension services and credit. Financial innovations aimed at providing such services like credit in a suitable way should be identified, since credit is an important support service for increased agricultural productivity. This is because credit enables producers to procure inputs, hire labour and equipment, etc (Ugbajah and Orji, 2006). Credit is also important because equity capital is seldom sufficient to meet the expenditure requirements for higher productivity and expand production. The need for credit is more severe in rural areas because access to local financial resources is restricted by the low productivity and widespread poverty of rural people (CBN, 2006). Furthermore, due to the fact that rural people are thought to be too poor to save or receive credits, efforts to mobilize domestic savings and provision of credit have for too long been concentrated in other sectors of the economy (UNDP, 2004).

The available sources of external funds for agriculture in Africa are development banks like the Bank of Agriculture, and the informal credit sources. It is in a bid to strengthen both credit sources to farmers that government merged it with Peoples Bank of Nigeria (PBN) and risks assets of the Family Economic Empowerment Programme (FEAP) to 


\section{www.ijtsrd.com}

become Bank of Agriculture. This started when preliminary report on rural financing was released on 27th May, 1999. Poor performance and duplication of duties were major reasons for merging them. The bank is a registered limited liability company. It is wholly owned and controlled by the federal government with the share capital fully subscribed by the Federal Ministry of Finance in corporation, having $60 \%$ share, while Central Bank of Nigeria has $40 \%$. The banks broad mandate encompasses savings mobilization and the timely delivery of affordable credit to meet the funding requirements of the farming Nigerian population in agricultural and non- agricultural sectors of the national economy (CBN, 2006).

According to CBN (2006), Bank of Agriculture provides all classes of agricultural loans for farming, livestock, fisheries, etc. under different portfolios. It is also charged with developing the economic base of the low income groups through the provision of loans, accepting savings to facilitate the repayment of such loans together with appropriate interest. It encourages the formation of cooperatives, good banking habits among Nigerians, especially the target group, capacity building through the training of beneficiaries on proper loan utilization, repayment, savings and the formulation of strategies for the profitable marketing of products. The credits are designed to target specific groups of beneficiaries for the execution of projects such as micro and macro credit loan scheme, livestock development project and fish production projects. The significance of the credit/loan scheme is aimed at increased agricultural productivity and improving farmers' income. It was believed that the introduction of the different credit loans in Bank of Agriculture would provide solutions to the credit problems of farmers.

Adejobi and Atobatele (2008) noted that loan default could limit access to credit, while Agnet (2004) asserted that the complex mechanism of commercial banking is least understood by the small-scale farmers, thus limits their access. Rahji and Fakayode (2009) blamed the limitation on imperfect and costly information problems encountered in the financial markets; credit rationing policy; and banks' perception of agricultural credit as a highly risky venture, while Philip et al (2009) reiterated that high interest rate and short term nature of loans with fixed repayment periods do not suit annual cropping, thus constitute a hindrance to credit access. Small-scale farmers in Enugu State, Nigeria are expected to have benefited from these credit/loan scheme. The question therefore is how many of these small-scale farmers have benefitted from the credit/loan scheme? Specifically, the objectives of the study were to:

identify sources of awareness of Bank of Agriculture credit/loan scheme;

$>$ ascertain benefits of credit/loan scheme to the respondents;

$>$ identify who guides the respondents on use of credits/loans;

$>$ ascertain problems of Bank of Agriculture credit/loan scheme; and

$>$ draw implications of credit/ loan scheme for extension service delivery.

\section{Methodology}

The study was conducted in Enugu State, Nigeria. Purposive and simple random sampling method were used to select four branches of Bank of Agriculture from the four agricultural zones in Enugu State. The beneficiaries were also purposively selected from Bank of Agriculture field offices thus Nsukka (15), Enugu town (15), Mgbowo (10) and Oji River (10) because of variance in population from existing list of participants. Also, 30 field officers/staff, eight (8) from three branches and six (6) from one of the branches were selected according to available staff size in each, giving a total of 100 respondents for the study. Data were collected through the use of interview schedule/structured questionnaire administered to both the farmers and Bank of Agriculture staff. Oral interview and focus group discussion (FGD) were also used to collect information from the respondents. Data were analyzed using frequency, percentage, mean scores and standard deviation.

\section{Results and Discussion}

Sources of awareness of Bank of Agriculture credit/loan scheme

Results of the study indicated that most farmers (35.7\%) learnt about the Bank of Agriculture facilities through radio (Table 1). This implies that radio play a prominent role in dissemination of agricultural information on loans, therefore more awareness can be created through the use of radio. About $23 \%$ of the respondents learnt about the credit/loan scheme from fellow farmers and colleagues, indicating that this means of communication also play 
fairly an important role. The table also revealed that $11.4 \%$ of the respondents learnt about the credit/loan scheme from extension agents. This implies that extension agents did not play prominent role in the dissemination of information to the farmers. The role of television $(7.1 \%)$ was the least. This could be attributed to the poor resources of the respondents in procuring and owning such electronic devices in their places of domicile as well as availability of electricity as indicated by the respondents through focus group discussions (FGD) and oral interviews.

Table 1: Distribution of respondents based on sources of awareness of Bank of Agriculture credit/loan scheme

\begin{tabular}{|l|l|l|}
\hline Sources of Awareness & Frequency & Percentage \\
\hline Television & 5 & 7.1 \\
\hline Radio & 25 & 35.7 \\
\hline $\begin{array}{l}\text { Extension } \\
\text { agents/services }\end{array}$ & 16 & 22.9 \\
\hline Cooperative societies & 8 & 11.4 \\
\hline $\begin{array}{l}\text { Friends/neighbors/fellow } \\
\text { Farmers/ colleagues }\end{array}$ & 16 & 22.9 \\
\hline
\end{tabular}

\section{Loan repayment by the beneficiaries}

Data in table 2 show the extent of loan repayment by the beneficiaries. The result of the study revealed that $100 \%$ of the respondents repaid loans within $1-3$ years after collection. It is mandatory that a given loan is paid back within a period of 1 to 3 years of disbursement indicating that the respondents kept to the rules in order to continue to enjoy benefits from the credit/loan scheme.
Table 2: Distribution of respondents based on loan repayment $(n=70)$

\begin{tabular}{|l|l|l|}
\hline No of years & Frequency & Percentage \\
\hline$<1$ & - & \\
\hline $1-3$ & 70 & 100 \\
\hline $4-6$ & - & - \\
\hline $7-9$ & - & - \\
\hline Above 10 & - & - \\
\hline
\end{tabular}

Data in table 3 revealed that out of the 5 schemes available, micro-credit was mostly patronized by farmers $(88.6 \%)$. Livestock development scheme was rated $11.4 \%$. The data also revealed that both the Economic Community of West African States (ECOWAS) fund scheme and International Fund for Agricultural Development (IFAD) project are meant to target fisher folks. Fishing is not a major occupation in Enugu State. This explains the nonpatronage of the two schemes together with animal traction and hand tools technology programme (ATHP).

Table 3: Distribution of respondents according to benefiting schemes $(n=70)$

\begin{tabular}{|c|c|c|c|c|}
\hline Benefiting schemes & Frequency & Amount applied & Amount received & Percentage \% \\
\hline Micro-credit scheme & 62 & Above $25,000.00$ & Above $25,000.00$ & 88.6 \\
\hline On-lending Scheme & - & - & - & - \\
\hline ECOWAS fund scheme & - & - & - & - \\
\hline IFAD project & - & - & - & - \\
\hline Livestock dev. Project & 8 & Above $25,000.00$ & Above $25,000.00$ & 11.4 \\
\hline
\end{tabular}




\section{Benefits of credit/loan scheme to the respondents}

Data in table 4 showed that $7.1 \%$ of the respondents use the credit for purchase of inputs for agricultural production, $55.7 \%$ of the respondents indicated using it for expansion of their farms, 32.9\% use theirs for purchase of farm machineries, while $1.4 \%$ use it for solving family problems. Only $2.9 \%$ use the credit for processing of agricultural products. This implies that majority of the farmers spend the credits on expansion of their farms and purchase of farm machineries. This will enhance agricultural production, increase income as well as improve their standard of living.

Table 4: Distribution of respondents according to benefits of credit/loan scheme $(n=70)$

\begin{tabular}{|l|l|l|}
\hline Benefits & Frequency & $\begin{array}{l}\text { Percentage } \\
(\%)\end{array}$ \\
\hline Purchase of farm inputs & 5 & 7.1 \\
\hline Expansion of farm & 39 & 55.7 \\
\hline $\begin{array}{l}\text { Purchase of farm } \\
\text { machineries }\end{array}$ & 23 & 32.9 \\
\hline $\begin{array}{l}\text { Building of house } \\
\text { Solving pressing family } \\
\text { problem }\end{array}$ & 1 & - \\
\hline $\begin{array}{l}\text { Processing of } \\
\text { agricultural products }\end{array}$ & 2 & 1.4 \\
\hline
\end{tabular}

\section{Guidance on credit and loan usage}

Table 5 revealed that $10 \%$ of the respondents were guided by fellow farmers, $22.9 \%$ were by cooperative societies, $15.7 \%$ by extension agents, while $51.4 \%$ were guided by Bank of Agriculture staff/officers in procuring loans. This implies that extension agents only play a minor role in guiding farmers on effective use of loans. This might lead to farmers diverting the loans / credits to other uses. This also implies that Bank of Agriculture staff played a major role in advising the farmers on how to use the loan. This is an indication that they are effective in the management of the credit facilities being offered; this will help to hasten timely loan repayment.

Table 5: Distribution of respondents according to guidance for effective loan usage $(n=70)$

\begin{tabular}{|l|l|l|}
\hline $\begin{array}{l}\text { Guidance } \\
\text { source }\end{array}$ & Frequency & Percentage \\
\hline Fellow farmers & 7 & 10.0 \\
\hline $\begin{array}{l}\text { Cooperative } \\
\text { society }\end{array}$ & 16 & 22.9 \\
\hline $\begin{array}{l}\text { Extension } \\
\text { agents }\end{array}$ & 11 & 15.7 \\
\hline $\begin{array}{l}\text { Bank of } \\
\text { Agriculture staff } \\
\text { /officers }\end{array}$ & 36 & 51.4 \\
\hline
\end{tabular}

\section{Problems of Bank of Agriculture credit/loan scheme}

It is evident on Table 6 that the respondents were constrained by late release of funds $(M=1.27)$, grace period too short $(M=1.17)$, excessive bureaucracy $(M=1.14)$, too short payback period $(M=1.13)$, services not regular $(M=1.13)$, among others. Standard deviation was also presented in Table 6. It was observed that standard deviation for all the problems were less than one. This shows that there is uniformity as regards the responses of the respondents which gave rise to no disparities on the various problems indicated by the respondents. This implies that late release of funds is a major problem hindering the respondents from obtaining credit/loans from Bank of Agriculture. Farming activities are seasonal so farmers need to have access to funds in time in order to commence planting of crops at the appropriate time. 
Table 6: Distribution of respondents according to problems of Bank of Agriculture credit/loan scheme $(\mathrm{n}=70)$

\begin{tabular}{|l|l|l|}
\hline \multicolumn{1}{|c|}{ Problem } & Mean Score & $\begin{array}{l}\text { Standard } \\
\text { Deviation }\end{array}$ \\
\hline High interest rate & 0.96 & 0.73 \\
\hline Late release of funds & 1.27 & 0.815 \\
\hline $\begin{array}{l}\text { Amount approved not } \\
\text { sufficient }\end{array}$ & 1.06 & 0.883 \\
\hline $\begin{array}{l}\text { Too short payback } \\
\text { period }\end{array}$ & 1.13 & 0.883 \\
\hline $\begin{array}{l}\text { Grace period too short } \\
\text { Excessive bureaucracy }\end{array}$ & 1.14 & 0.816 \\
\hline Services not regular & 1.13 & 0.839 \\
\hline
\end{tabular}

\section{Problems of Bank of Agriculture credit/loan scheme by staff}

The major problems faced by staff of Bank of Agriculture on credit/loan scheme were late release of approved funds by head quarters of the Bank of Agriculture $(M=1.43)$, loan diversion $(M=1.27)$, poor funding of field officers $(M=1.20)$, lack of awareness by borrowers $(\mathrm{M}=1.10)$ and insufficient staff $(M=0.93)$ (Table 7). Standard deviation was also shown in Table 7 which indicates that all the problems were less than one, showing the uniformity in responses of the respondents on constraints to credit/loan scheme. The late release of funds can lead to misuse when it is finally made available because the respondents may not have the need for its usage as a result of wrong timing. Ayegba (2013) stated that banks should understand that cropping is

seasonal and depends on several climatic conditions and must endeavour to fast track the loan processing turnaround time in the best interest of rural farmers. Oyeyinka (2002) reiterated that improved access to credit enables households to invest in farm assets and therefore increase income levels of beneficiaries.

Table 7: Mean scores on problems of Bank of Agriculture credit /loan facilities by staff $(n=30)$

\begin{tabular}{|l|l|l|}
\hline Problem & $\begin{array}{l}\text { Mean } \\
\text { Score }\end{array}$ & $\begin{array}{l}\text { Standard } \\
\text { Deviation }\end{array}$ \\
\hline $\begin{array}{l}\text { Lack of awareness by } \\
\text { borrowers }\end{array}$ & 1.10 & 0.71 \\
\hline Insufficient staff & 0.93 & 0.52 \\
\hline $\begin{array}{l}\text { Late release of approved } \\
\text { funds by head quarters }\end{array}$ & 1.43 & 0.73 \\
\hline $\begin{array}{l}\text { Loan diversion field } \\
\text { Poor funding of } \\
\text { officers }\end{array}$ & 1.27 & 0.74 \\
\hline
\end{tabular}

\section{Implications for sustainable credit/loan scheme provision to farmers}

Findings of the study indicated that funds were made available to the farmers through the new credit/loan scheme created in Bank of Agriculture. The branch network of the bank in Enugu State and other parts of the country make it easier to reach the remote areas provided that adequate logistic is made available to the staff of the bank. The implication of this is that the rural farmers should exploit the opportunity of the credit /loan scheme within their areas to boost food production to ensure self-sufficiency in agricultural production. Extension agents should therefore intensify efforts in popularizing the benefits of the credit/loan scheme to the rural farmers. Major constraint to provision of the credit/loan scheme was late release of funds. This problem should be addressed adequately through timely release of funds especially the popular micro-credit scheme commonly patronized by the rural farmer beneficiaries. There is therefore need for more awareness campaigns to be created by Bank of Agriculture to enable farmers become aware of their services and equally benefit 
from them. This could be achieved through radio and television advertisement, church announcement, public announcements during village and town meeting, use of print media such of newspapers, bulletins, etc. More extension agents and credit experts should be employed and trained for more effective and wider coverage of small holder farmers in terms of supervision and guidance. This will ensure easy dissemination of information and proper monitoring on the use of such funds. Also, mandatory deposit scheme should be organized and introduced. This will help beneficiaries cultivate the habit of saving, thus increasing the ability to repay the loans.

\section{Conclusion and Recommendations}

Radio is the major source of awareness of Bank of Agriculture credit/loan scheme in Enugu State, Nigeria for the respondents. The respondents were mostly guided on the use of funds by staff of Bank of Agriculture in order to avoid inappropriate usage. Major constraint to accessing funds as observed by the farmers was late release of funds, while staff of Bank of Agriculture also indicated late release of approved funds at the head quarters of the Bank of Agriculture. The study recommends that adequate awareness campaign on the availability of microcredit/loan scheme by Bank of Agriculture should be created in order for the beneficiaries to be knowledgeable about it. It highlights the need for approval of more funds under the scheme and timely release of funds when needed especially during planting season in order to enable the farmers to make judicious use of it for optimum productivity.

\section{References}

Adejobi O. and Atobatele,J.T. (2008) An analysis of loan delinquency among small-scale farmers in Southwestern Nigeria: Application of Logit and Loan Performance Indices. East

African Agricultural and forestry Journal, 74 (3):3438. Agnet (2004). Making Farm Credit Work for the Small Scale farmers (www.agnet.org/library).
Ayegba, O. and Ikani, D.I. (2013). An Impact Assessment of Agricultural Credit on Rural Farmers in Nigeria. Research Journal of Finance and Accounting, 4 (18): 80- 89.

Central Bank of Nigeria (2006). Economic Review, 6 (2):24.

Ekong, E. E. (2003). An introduction to Rural Sociology, 2nd ed.; Dove education publishers, Uyo, pp. 404.

Oyeyinka, R. A. (2002). Impact of (NACRDB) Smallholder Direct Loan Scheme on Farmers in Oyo State Nigeria, Ph.D. Thesis Department of Agricultural Extension and Rural Development, University of Ibadan.

Phillip, D, Nkonya, E, Pender. J and Oni, O.A. (2009). Constraints to Increasing Agricultural

Productivity in Nigeria: A review. Nigeria Strategy Support Program (NSSP), Background paper No. NSSP006.

Rahji, M. A. Y and Fakayode, S.A. (2009). A Multinomial Logit analysis of Agricultural Credit

Rationing by Commercial Banks in Nigeria. International Research Journal of Finance and Economics, 24: 91. www.eurojournals.com/finance.

Ugbajah M.O. and Orji E.C. (2006). Studies on the determinants of access to financial services among male and female farmers in Anambra State. Proceedings of the 40th Annual conference of the Agricultural Society of Nigeria, pp.110-114.

United Nations Development Programme (UNDP) (2004). Nigeria Development profile. Development Profile. March 2004. 